\title{
Effect of acetylcholinesterase inhibitors in the Alzheimer patients on the daily cardiovascular neurovegetative assessment
}

\author{
G. Raimondi ${ }^{1}$, N. Marchitto ${ }^{2}$, B. Scordamaglia ${ }^{1}$, A. Ciaramella ${ }^{1}$, I. Masci ${ }^{1}$ \\ P. Casacci ${ }^{3}$, M. Pistoia ${ }^{3}$, S. Sacco ${ }^{1}$, G. Sancesario ${ }^{4}$ \\ ${ }^{1}$ University of Roma «Sapienza», Italy \\ ${ }^{2}$ ASL Latina, Italy \\ ${ }^{3}$ Liferesult, Italy \\ ${ }^{4}$ University «Tor Vergata», Roma, Italy
}

\begin{abstract}
Introduction. The acetylcholinesterase inhibitor (CI) has recently been used for the treatment of senile dementia of Alzheimer type. Therefore, conflicting results exist in the literature on the action of the CI in the cardiovascular neurovegetative regulation.

Aim. In this concern we worked on the ability to remotely monitor patients with dementia in their own homes, with the support of high-tech devices.

Materials and Methods. We studied 36 patients ( $17 \mathrm{~F}$ and $19 \mathrm{M}, 74,5 \pm 8,4$ years). At the patients we installed a new devices «Pulse» for a week. From the device we can obtain a record for 5-minute each hour in which the ECG, breath frequency, body position and activity level are reported.

From the records we can extrapolate by means of KUBIOS-HRV software the HRV analysis, both linear and nonlinear. We divided the patients in two groups: in therapy with CI (19-9 F, 72,6 $\pm 7,6$ years) and without CI ( $17-8 \mathrm{~F}, 75,3 \pm 10,1$ years). The CI administered generally was Donezepil or rivastigmine.

Result. In the morning the indexes of sympathetic tone were more significant high in the patients with CI inhibitors respect to the patients without CI therapy and to the normal control, no differences were present between the control group and thee patients without CI therapy. Respect to patients without CI therapy in the patients with CI therapy we found a surprisingly greater and significant increase in sympathetic activity in all period considered specially during the night periods despite no difference in HR. In fact the linear and nonlinear indexes of the HRV of sympathetic activity was significantly higher in all considered daily period.

Conclusion. Our data, obtained in telemedicine by means a new device «Pulse», show the sympathetic HRV indexes are significantly high in patients with CI therapy in all period of the day and this fact is more pronounced during the night hours.
\end{abstract}

Key words: Telemedicine; HRV; Acetylcholinesterase inhibitor; Alzheimer.

${ }^{\odot} 2018$ Institute Medical Informatics and Telemedicine Ltd, $\odot 2018$ Ukrainian Association for Computer Medicine, ${ }^{\odot} 2018$ Kharkiv medical Academy of Postgraduate Education. Published by Institute of Medical Informatics and Telemedicine Ltd. All rights reserved.

ISSN 1812-7231 Klin. inform. telemed. 2018, vol. 13, iss. 14, pp. 32-36. https://doi.org/10.31071/kit2018.14.04

http://kit-journal.com.ua/en/index_en.html

References (16)

\section{Introduction}

The acetylcholinesterase inhibitor has recently been used for the treatment of senile dementia of Alzheimer type but they have systemic actions that can affect cardiovascular and autonomic nervous system (ANS)

$\mathrm{Cl}$ is a commonly used treatment for myasthenia gravis. Pyridostigmine, a peripheral acetylcholinesterase inhibitor, should increase the availability of acetylcholine at both ganglionic nicotinic acetylcholine receptors (with a resultant increase in both sympathetic and parasympathetic tone) and postganglionic muscarinic acetylcholine receptors (which increases parasympathetic tone).

The cholinergic activity of acetylcholinesterase inhibitors and the anticholinergic properties of the antipsychotics agents are both related to the vagal modulation that can be observed from the surveys of the electrocardiogram (ECG). We hypothesized that the early ECG recording with remote control can be predictive of not only the side effects of treatment with neuroleptics and with acetylcholinesterase inhibitors, but also the neurovegetative cardiovascular daily assessment.

Therefore, conflicting results exist in the literature on the action of the $\mathrm{Cl}$ in the cardiovascular neurovegetative regulation

In this concern we worked on the ability to remotely monitor patients with dementia in their own homes, with the support of high-tech devices. Our approach required the monitoring of several parameters not only the cardiovascular circadian rhythms, but also the respiratory activity and movement, thus providing a more complete and comprehensive appreciation of the person in his normal everyday activities. The chosen devices to employ in the work were a wearable device (detector of heart parameters), a tablet to collect data at the patient's premises, and a cloud server to compute data. By means the technological partner Life result, normally engaged in the study of information technology solutions for life-sciences.

The vital parameter detection device used was MR\&D's Pulse Sensor ${ }^{\mathrm{TM}}$, based on ST Microelectronics BodyGateway ${ }^{\mathrm{TM}}$ chipset. 
For the neurovegetative cardiovascular control we used HRV as a non-invasive marker of the activity of the autonomic nervous system. It is dependent predominantly on the extrinsic regulation of the heart rate.

\section{Material and Methods}

We studied 139 patients from the Regional Centre of Alzheimer's Policlinico Tor Vergata. 58 Patients were enrolled but only 36 patients ( $17 \mathrm{~F}$ and $19 \mathrm{M}, 74,5 \pm 8,4$ years) completed the study. The dropouts were due to lack of caregivers or errors committed by caregivers during data acquisition. At the patients we installed a pulse for a week.

We divided the patients in two groups: in therapy with $\mathrm{Cl}(19-9 \mathrm{~F}$, $72,6 \pm 7,6$ years) and without $\mathrm{Cl}$ (17-8 F, 75,3 $\pm 10,1$ years), The $\mathrm{Cl}$ administered generally was Donezepil or rivastigmine. 14 patients were suffering from hypertension, 5 from diabetes, 7 from ischemic heart disease, equally distributed between the two groups.

We studied also a normal old group (13 subjects, $6 \mathrm{~F}$, age: $72,3 \pm 4,9$ years) without any therapy, enrolled in the Universitary Operative Unit of Cardiology of the "Sapienza». In this case we recorded the digital ECG by means Cardiolab System (XAI-Medica). (Tab. 1)

In all patients we utilized the Pulse. It is a wearable, battery operated device intended for use as a part of a multiparameter analysis system. It uses a sensorized component adhesive (plaster), placed on the body of the assisted person. The device permits to record heart rate, respiratory rate and, through a specific algorithm, the level of activity of the person, providing the management system of continuous or periodic messages of information to/from the server according to specific settings defined by operators.

From the device we can obtain a record for 5 -minute each hour in which the ECG (signal and R-R interval), breath frequency, position and activity level are reported; then in the day we can potentially observe 24 records and we have the possibility to have not only the ECG abnormalities (arrhythmias or conduction's defects) but also the neurovegetative assessment during the normal activity.

From the records we can extrapolate by means of KUBIOSHRV software the HRV analysis, both linear and nonlinear. Linear methods include traditional statistical analysis (SDNN, RMSSD) and the analysis of the HRV through the frequency domain calculating the LF, HF and LF/HF Ratio components. Nonlinear methods include the Poincarè plot (SD1 and SD2 indexes) and the Detrended Fluctuation Analysis (DFA - $\alpha 1$ and $\alpha 2$ indexes).

Assessment of HRV provides quantitative information about the modulation of heart rate (HR) by sympathetic nervous system (SNS) and parasympathetic nervous system (PNS). Interactions of SNS and PNS using HRV signal have been well studied and their importance established with a number of cardiac diseases including myocardial infarction, patients with congestive heart failure, patients at risk of sudden cardiac death and patients with hypertension. There are two main approaches to the analysis of HRV: time-domain and frequency-domain analysis.

Frequency-domain analysis, which is based on the power spectral density of the heart rate time series, highlights the issue of the underlying rhythms of the mechanisms controlling heart rate (HR) and identified three major spectral peaks high frequency (HF: 0,15-0,4 Hz), low frequency (LF: $0,04-0,15 \mathrm{~Hz}$ ) and very low frequency (VLF: below $0,04 \mathrm{~Hz}$ )) in the adult HR spectrum.

LF reflects both sympathetic and para-sympathetic activity. Generally it is a strong indicator of sympathetic activity. HF reflects parasympathetic (vagal) activity. LF/HF ratio indicates overall balance between sympathetic and parasympathetic systems. Higher values reflect domination of the sympathetic system, while lower ones - domination of the parasympathetic system. This ratio can be used to help quantify the overall balance between the sympathetic and parasympathetic systems. As concerns nonlinear analysis, namely Poincarè plots, a two-dimensional vector analysis was used to quantify the shape of the plots. In this quantitative method, short-term (SD1) and long-term (SD2) R-R interval variability and the ellipse area of the plot are quantified separately. SD1 is considered to reflect vagal modulation of the sinus node. As concerns Detrended fluctuation analysis (DFA), this technique is used to quantify the fractal scaling properties of short- and intermediate-term R-R interval time series. The HR correlations were defined separately for short-term ( $<11$ beats, $\alpha 1)$ and longerterm ( $>11$ beats, $\alpha 2$ ) R-R interval data. The $\alpha 1$ index was positively correlated with LF in normalized units.

Rather than evaluating 24 periods in the day, in our opinion it was better to analyze these periods:

- the morning $(8.00$ a.m.) in which the sympathetic activity is high;

- the afternoon (16.00) in which there is a decrease of the sympathetic activity

- the evening (20.00 p.m) in which there is an increase of the sympathetic activity

- the night (2.00 a.m.), in these periods the parasympathetic activity increases.

With this analysis, it is possible to better explore the daily cardiovascular neurovegetative pattern of the patients.

\section{Results}

In all the patients enrolled the ECG conduction was not influenced by neurological therapy, but in each period considered the indexes of the sympathetic activity, both linear in the time and in the frequency domain and non linear showed a marked increase also during the night period in which the rest was confirmed by the low indexes of the activity level and then it there should be an increase in vagal tone. In fact he activity level, expressed in arbitrary unit (scale 1-15), showed a minimal activity during night period in both groups $(\mathrm{Cl}=1,2 \pm 1,7, \mathrm{NOCl}=1,25 \pm 2,5)$. Pic. 1 .

Tab. 1. Demographic and Clinical Characteristics.

\begin{tabular}{|l|c|c|c|c|}
\hline & $\begin{array}{c}\text { Control } \\
(\mathbf{1 3 - 6} \mathbf{F})\end{array}$ & $\begin{array}{c}\text { NO-CI } \\
(\mathbf{1 7 - 8} \mathbf{F})\end{array}$ & $\begin{array}{c}\text { Cl } \\
(\mathbf{1 9 - 7} \mathbf{~ F})\end{array}$ & P \\
\hline Age (years) & $72,3 \pm 4,9$ & $75,3 \pm 10,1$ & $72,6 \pm 7,6$ & NS \\
\hline SAP $\mathrm{mmHg}$ & $143,1 \pm 11,1$ & $138, \pm 10,7$ & $132,2 \pm 9,1$ & NS \\
\hline DAP $\mathrm{mmHg}$ & $80,8 \pm 9,5$ & $83,7 \pm 7,9$ & $77,8 \pm 6,9$ & NS \\
\hline BMI $\left(\mathrm{cm} / \mathrm{Kg}^{2}\right)$ & $26,5 \pm 1,6$ & $24,7 \pm 2,8$ & $24,2 \pm 2,9$ & NS \\
\hline
\end{tabular}


IT в психіатії, ВСР, телемедицина, мобільна медицина

In the morning the indexes of sympathetic tone were more significant high in the patients with $\mathrm{Cl}$ inhibitors respect to the patients without $\mathrm{Cl}$ therapy and to the normal control, no differences were present between the control group and thee patients without Cl therapy. (Tab. 2).

Respect to patients without $\mathrm{Cl}$ therapy in the patients with $\mathrm{Cl}$ therapy we found a surprisingly greater and significant increase in sympathetic activity in all period considered specially during the night periods despite no difference in HR. In fact the linear and nonlinear indexes of the HRV of sympathetic activity was significantly higher in all considered daily period. (Tab. 3)

The R-R interval showed, as expected, an increase during the night but without significant differences between the 2 groups. (Tab. 4).

The data are expressed as Mean \pm SD

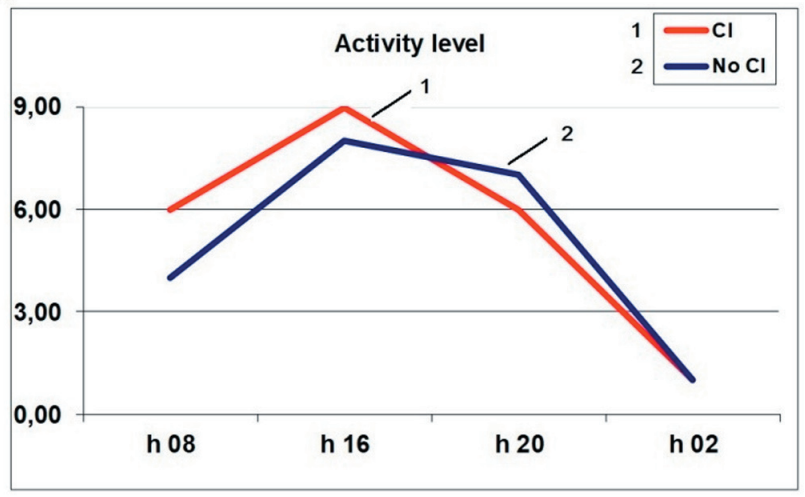

Pic. 1. Activity level during the day.

Tab. 2. Sympathetic activity indexes in the morning.

\begin{tabular}{|c|c|c|c|c|}
\hline & Control & NO-Cl & Cl & P \\
\hline LF/HF & $2,03 \pm 1,6$ & $1,858 \pm 1,195$ & $3,404 \pm 2,105$ & $0,012 *$ \\
\hline$\alpha 1$ & $1,01 \pm 0,2$ & $1,048 \pm 0,227$ & $1,222 \pm 0,251$ & $0,037 *$ \\
\hline SD2/SD1 & $1,68 \pm 0,5$ & $1,783 \pm 0,449$ & $2,169 \pm 0,629$ & $0,043^{*}$ \\
\hline
\end{tabular}

$*=\mathrm{Cl}$ vs $\mathrm{NO}-\mathrm{Cl}$

Tab. 3. Sympathetic activity during the day in the patients with dementia.

\begin{tabular}{|c|c|c|c|c|}
\hline & & $\mathrm{NO}-\mathrm{Cl}$ & $\mathrm{Cl}$ & $\mathbf{P}$ \\
\hline \multirow[t]{3}{*}{ h. 8.00} & $\mathrm{LF} / \mathrm{HF}$ & $1,858 \pm 1,195$ & $3,404 \pm 2,105$ & 0,012 \\
\hline & $\alpha 1$ & $1,048 \pm 0,227$ & $1,222 \pm 0,251$ & 0,037 \\
\hline & SD2/SD1 & $1,783 \pm 0,449$ & $2,169 \pm 0,629$ & 0,043 \\
\hline \multirow[t]{3}{*}{ h. 16.00} & $\mathrm{LF} / \mathrm{HF}$ & $1,529 \pm 1,055$ & $3,350 \pm 2,602$ & 0,011 \\
\hline & $\alpha 1$ & $0,964 \pm 0,222$ & $1,189 \pm 0,313$ & 0,019 \\
\hline & SD2/SD1 & $1,594 \pm 0,654$ & $2,124 \pm 0,701$ & 0,025 \\
\hline \multirow[t]{3}{*}{ h. 20.00} & $\mathrm{LH} / \mathrm{HF}$ & $1,222 \pm 0,787$ & $3,814 \pm 4,411$ & 0,023 \\
\hline & $\alpha 1$ & $0,883 \pm 0,276$ & $1,126 \pm 0,338$ & 0,025 \\
\hline & SD2/SD1 & $1,510 \pm 0,511$ & $2,025 \pm 0,763$ & 0,025 \\
\hline \multirow[t]{3}{*}{ h. 02.00} & $\mathrm{LH} / \mathrm{HF}$ & $1,222 \pm 0,787$ & $3,814 \pm 4,411$ & 0,023 \\
\hline & $\alpha 1$ & $0,883 \pm 0,276$ & $1,126 \pm 0,338$ & 0,025 \\
\hline & SD2/SD1 & $1,510 \pm 0,511$ & $2,025 \pm 0,763$ & 0,025 \\
\hline
\end{tabular}

Tab. 4. R-R interval during the day in the patients with dementia.

\begin{tabular}{|l|c|c|c|}
\hline R-R msec & NO-CI & Cl & P \\
\hline h 08.00 & $865,9 \pm 122,5$ & $894,4 \pm 175,2$ & 0,581 \\
\hline h 16.00 & $836,8 \pm 118,6$ & $849,7 \pm 137,0$ & 0,766 \\
\hline h 20.00 & $847,8 \pm 143,8$ & $853,1 \pm 129,2$ & 0,909 \\
\hline h. 02.00 & $980,2 \pm 147,9$ & $1015,2 \pm 126,8$ & 0,451 \\
\hline
\end{tabular}




\section{Discussion}

Several studies have suggested a clinically beneficial role for acetylcholinesterase inhibitors in other autonomic disorders, with one study noting an incidental bradycardia. It has been hypothesized that this «double hit» of increasing parasympathetic tone at 2 points on the autonomic pathway might result in increased cardiovagal tone and a decreased heart rate.

On the other hand $\mathrm{Cl}$ appears effective in the treatment of neurogenic orthostatic hypotension. In fact the augmentation in sympathetic tone with acetylcholinesterase inhibition has proven clinically useful in patients with orthostatic hypotension. Some authors report that peripheral acetylcholinesterase inhibition increased blood pressure among patients with autonomic failure Nobrega et al. report that blunted the pressor and chronotropic responses to mental stress in healthy young subjects.

Therefore, conflicting results exist in the literature on the action of the $\mathrm{Cl}$ in the cardiovascular neurovegetative regulation.

We used the HRV analysis both with linear and non-linear methods and we interpret the ratio of SD2/SD1 as a measure of the balance between long- and short-term HRV by its analogy and similar properties to LF/HF. In both ratios the numerators correspond to a parameter depending on both long-term (low frequency) and short-term (high frequency) variability, and the denominators depend solely on short-term variability. These indexes correlate most strongly with LF/HF. Finally also $\alpha 1$ index, derived from the Detrended Fluctuation Analysis is considered an index of the sympathetic tone, in fact the reduction of the $\alpha 1$ index is a predictor of mortality in patients with ischemic cardiac diseases or heart failure.This technique is used to quantify the fractal scaling properties of short- and intermediate-term R-R interval time series. The HR correlations were defined separately for short-term (<11 beats, $\alpha 1)$ and longer-term (>11 beats, $\alpha 2$ ) $\mathrm{R}$ - $\mathrm{R}$ interval data.

Our data show the sympathetic indexes analyzed by means HRV are significantly hig in patients with $\mathrm{Cl}$ therapy in all period of the day and this fact is more pronounced during the night hours.

\section{Transparency}

Declaration of financial/other relationships: None.

Author contributions: none.

\section{References}

1. Akselrod S., Gordon D., Ubel F. A., Shannon D. C., Berger A. C., Cohen R. J. Power spectrum analysis of heart rate fluctuation: a quantitative probe of beat-to-beat cardiovascular control. Science. 1981, vol. 213 (4504), pp. 220-222.

2. Balocchi R., Cantini F., Varanini M., Raimondi G., Legramante J. M., Macerata A. Revisiting the potential of time-domain indexes in short-term HRV analysis. Biomed. Tech., 2006, iss. 51, pp. 190-193.

3. Fukusaki C., Kawakubo K., Yamamoto Y. Assessment of the primary effect of aging on heart rate variability in humans. Clin. Auton. Res., 2000, vol. 10, pp. 123-130.

4. Joaquim L. F., Farah V. M., Bernatova I., Fazan R. Jr., Grubbs R., Morris M. Enhanced heart rate variability and baroreflex index after stress and cholinesterase inhibition in mice. Am. J. Physiol. Heart Circ. Physiol., 2004, iss. 287, H251-H257.
5. Killian T. J., Robertson D., Biaggioni I., Haile V., Biscaia I., Robertson R. M. Sympathetic nervous system function in man is enhanced by acetylcholinesterase inhibition. Circulation, 1990 , iss. 82, III-636.

6. Malliani A., Pagani M., Lombardi F., Cerreti S. Cardiovascular neural regulation explored in the frequency domain. Circulation, 1991, vol. 84, iss. 2, pp. 482-492.

7. Martynenko A., Yabluchansky M., Kantor B. Mathematical model of automatic nervous systems. Technology and health care: J. Europ. Society for Engineering and Medicine, 2001, iss. 9, pp. 174-176.

8. Masuda Y.; Kawamura A. Acetylcholinesterase Inhibitor (Donepezil Hydrochloride) Reduces Heart Rate Variability. J. Cardiovasc. Pharmacol., 2003, vol. 41, pp. 67-71.

9. Mäkikallio T. H., et al. Prediction of sudden cardiac death by fractal analysis of heart rate variability in elderly subjects. J. Am. Coll. Cardiol., 2001, vol. 37, pp. 1395-1402.

10. Raimondi G., Legramante J. M., Scordamaglia B., Masci I., Montanari G., Pampena R., Skroza N., Potenza M. C. Linear and non-linear R-R interval variability analysis in the neurovegetative cardiovascular assessment in Psoriasis and Obesity. Appl. of Inform. Systems in Engineering and Biosci., 2014, pp. 61-69.

11. Raj S. R., Black B. K., Biaggioni I., Harris P. A., Robertson D. Acetylcholinesterase inhibition improves tachycardia in postural tachycardia syndrome. Circulation, 2005, vol. 31, pp. 2734-2740.

12. Siepmann M., Mück A., Engel S., Rupprecht R. The Influence of Rivastigmine and Donepezil on Heart Rate Variability in Patients with Alzheimer's Disease. German J. Psychiatry, 2006 iss. 9, pp. 133-135.

13. Sindona F., Raimondi G., Pecchia R., Spaziani E., Masci I., Scordamaglia B. The effects of general anaesthesia on heart rate variability during abdominal surgery. J. Medicine, Physiology and Biophysics, 2015, vol. 18, pp. 93-99.

14. Stein R. D., Backman S. B., Collier B., et al. Bradycardia produced by pyridostigmine and physostigmine. Can. J. Anaesth. 1997, vol. 44, pp. 1286-1292.

15. Yamamoto Y., Nakamura Y., Sato H., Yamamoto M., Kato K., and Hughson R. L. On the fractal nature of heart rate variability in humans: effects of vagal blockade. Am. J. Physiol. Regul. Integr. Comp. Physiol., 1995, iss. 269, R830-R837.

16. Yamasaki Y., Kodama M., Matsuhisa M., et al. Diurnal heart rate variability in healthy subjects: effects of aging and sex difference. Am. J. Physiol., 1996, iss. 271, H303-310.

\section{Corresponding author}

Gianfranco Raimondi, Associated professor of Internal Medicine «Sapienza» University of Roma, Italy mobile phone: 00393286112942 e-mail: gianfrancoraimondi@uniroma1.it 


\title{
Вплив інгібіторів ацетилхолінезтерази у пацієнтів 3 хворобою Альцгеймера на щоденну серцево-судинну нейровегетативну оцінку
}

\author{
G. Raimondi ${ }^{1}$, N. Marchitto ${ }^{2}$, B. Scordamaglia ${ }^{1}$, A. Ciaramella ${ }^{1}$, I. Masci ${ }^{1}$, P. Casacci ${ }^{3}$ \\ M. Pistoia ${ }^{3}$, S. Sacco ${ }^{1}$, G. Sancesario ${ }^{4}$ \\ ${ }^{1}$ University of Roma «Sapienza», ${ }^{2}$ ASL Latina, ${ }^{3}$ Liferesult, ${ }^{4}$ University «Tor Vergata», Roma
}

\begin{abstract}
Резюме
Вступ. Інгібітор ацетилхолінестерази (IA) недавно був використаний для лікування старечої деменції типу хвороби Альцгеймера. Таким чином, в літературі існують суперечливі результати про дії IA на серцево-судинну нейровегетативну регуляцію.

Мета. У зв'язку з цим ми працювали над можливістю віддаленого моніторингу пацієнтів з деменцією в їх власних будинках за підтримки високотехнологічних пристроїв.

Матеріали та методи. 0бстежено 36 пацієнтів (17 жінок (F) і 19 чоловіків (M), 74,5 \pm 8,4 років). У пацієнтів ми встановили на тиждень новий пристрій «Пульс». За допомогою пристрою можна отримати запис тривалістю 5 хвилин щогодини, в якій — ЕКГ, частота дихання, положення тіла і рівень активності.

Із записів за допомогою програмного забезпечення KUBIOS-HRV можна провести лінійний і нелінійний аналіз ВСР. Ми розділили

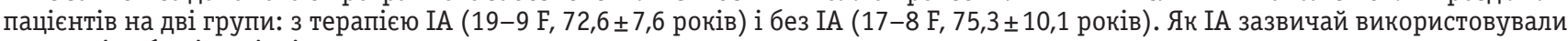
донезепіл або рівастігмін.

Результати. Вранці показники симпатичного тонусу були більш значущими у пащієнтів з інгібіторами IA в порівнянні $з$ пацієнтами без терапії IA і з нормальним контролем. Ніяких відмінностей між контрольною групою і хворими, які не мали терапію IA не було. У пацієнтів без терапії IА в порівнянні з пацієнтами, які отримували терапію IА, виявили більше і значне збільшення симпатичної активності в усьому періоді, особливо в нічні періоди, незважаючи на відсутність відмінностей в ЧСС. Лінійні і нелінійні показники ВСР симпатичної активності були достовірно вище у всіх розглянутих добових періодах.

Висновок. Наші дані, отримані за допомогою нового пристрою «Пульс» для телемедицини, показують, що симпатичні індекси ВСР у пацієнтів з IА протягом усього дня значно вище, і цей факт більш виражений в нічні години.
\end{abstract}

Ключові слова: телемедицина; ВСР; інгібітор ацетилхолінестерази; хвороба Альцгеймера.

\section{Влияние ингибиторов ацетилхолинэстеразы у пациентов с болезнью Альцгеймера на ежедневную сердечно-сосудистую нейровегетативную оценку}

\author{
G. Raimondi ${ }^{1}$, N. Marchitto ${ }^{2}$, B. Scordamaglia ${ }^{1}$, A. Ciaramella ${ }^{1}$, I. Masci ${ }^{1}$, P. Casacci ${ }^{3}$ \\ M. Pistoia ${ }^{3}$, S. Sacco ${ }^{1}$, G. Sancesario ${ }^{4}$ \\ ${ }^{1}$ University of Roma «Sapienza», ${ }^{2}$ ASL Latina, ${ }^{3}$ Liferesult, ${ }^{4}$ University «Tor Vergata», Roma
}

\section{Резюме}

Введение. Ингибитор ацетилхолинэстеразы (ИА) недавно был использован для лечения старческого слабоумия типа болезни Альцгеймера. Таким образом, в литературе существуют противоречивые результаты о действии ИА на сердечно-сосудистую нейровегетативную регуляцию.

Цель. В связи с этим мы работали над возможностью удаленного мониторинга пациентов с деменцией в их собственных домах при поддержке высокотехнологичных устройств.

Материалы и методы. Обследовано 36 пациентов (17 женщин (F) и 19 мужчин (M), 74,5 \pm 8,4 года). У пациентов мы установили на неделю новое устройство «Пульс». С помощью устройства можно получить запись длительностью 5 минут каждый час, в которой - ЭКГ, частота дыхания, положение тела и уровень активности.

Из записей с помощью программного обеспечения KUBIOS-HRV можно провести линейный и нелинейный анализ ВСР. Мы раз-

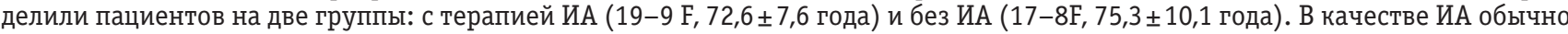
использовали донезепил или ривастигмин.

Результат. Утром показатели симпатического тонуса были более значимыми у пациентов с ингибиторами ИА по сравнению с пациентами без терапии ИА и с нормальным контролем. Никаких различий между контрольной группой и пациентами без терапии ИА не было. У пациентов без терапии ИА по сравнению с пациентами, получавшими терапию ИА, обнаружили удивительно большее и значительное увеличение симпатической активности во всем периоде, особенно в ночные периоды, несмотря на отсутствие различий в ЧСС. Линейные и нелинейные показатели ВСР симпатической активности были достоверно выше во всех рассматриваемых суточных периодах.

Заключение. Наши данные, полученные с помощью нового устройства «Пульс» для телемедицины, показывают, что симпатические индексы ВСР у пациентов с ИА в течение всего дня значительно выше, и этот факт более выражен в ночные часы. Ключевые слова: телемедицина; ВСР; ингибитор ацетилхолинэстеразы; болезнь Альцгеймера. 